The Bourgeoisie and Democracy:

Historical and Contemporary Perspectives from Europe and Latin America

\author{
Evelyne Huber and John D. Stephens
}

Prepared for delivery at the 1997 meeting of the Latin American Studies Association, Continental Plaza Hotel, Guadalajara, Mexico, April 17-19, 1997.

Comments welcome. Send communications to Department of Political Science, University of North Carolina, Chapel Hill, NC 27599-3265, phone - 919-932-1168, fax 919-962-0398; EMail: ehuber or jsteph @unc.edu. 
The historical role of the bourgeoisie in creating and maintaining political democracy has been much disputed in the social science literature. On the one hand, liberal social scientists and most Marxist analysts writing on European historical development cast the bourgeoisie, the owners of the principal means of non-agricultural production in capitalist societies, in the role of the main agent promoting political democracy (however, see Therborn 1978). By contrast, class analytic social scientists writing on the Third World have assigned the bourgeoisie a far less heroic role. In O'Donnell's $(1973,1978)$ analysis of the rise of bureaucratic authoritarianism in Latin America, the bourgeoisie was a key partner, along with the military, in the eclipse of democracy in the late 1960s and the 1970s.

This question is not only important for the historic record and social science theory but also for the political question of the prospects for democracy in Latin America and elsewhere in the Third World. There is no doubt that there is an affinity between capitalist development and democracy both synchronically, at least in the long durée, and diachronically across countries at different levels of development. But if this long term development occurred despite the political efforts of the bourgeoisie and not because of them, then this has very different implications for the future of political democracy and the quality of democracy in Latin America and other regions of the Third World where bourgeois economic and political dominance is only weakly contested.

In this essay, we will examine the historic and contemporary role of the bourgeoisie in the development, demise, and stabilization of political democracy in Western Europe, Latin America, and the Caribbean. Our necessarily brief sketch of the historic development, which largely recapitulates our previous work on this topic (Rueschemeyer, Stephens, and Stephens 1992), is an essential background to our analysis of the contemporary period. We argue that democracy was established in most countries in these regions despite the efforts of the bourgeoisie, because capitalist development strengthened the working and middle classes and weakened large landlords. The bourgeoisie generally sided with the anti-democratic forces particularly in the later stage of political development when the struggle for democracy turned from establishing parliamentary government to extending political rights to the masses. As for the post World War II period in Western Europe, we argue that democracy was stabilized, rountinized, and accepted by virtually all social actors and political parties because it was accompanied by a class compromise in which all major parties material interests were secured and a modicum of political influence was extended to the working class, even in countries where the political right and business were politically dominant. By contrast, no such class compromise has accompanied the transition to democracy in post authoritarian Latin American. We contend that, given this situation, there is the distinct possibility that democracy could be reversed if bourgeois dominance is contested, or that at least the quality of democracy, which is highly deficient already, will deteriorate even more. 


\section{The Theory of Democratic Development}

We adopt a conventional definition of democracy: regular free and fair elections of representatives on the basis of universal suffrage; responsibility of the state apparatus to the elected representatives of the people; and guarantees for freedom of expression and association. We argue that the development of democracy is the product of three clusters of power: (1) the balance of class power as the most important aspect of the balance of power in civil society, (2) the nature of the state and state-society relations, or the balance of power between state and civil society, and (3) transnational structures of power, or the international economy and system of states, as they shape the first two balances and constrain political decision-making. ${ }^{1}$

The central thesis of our book is that capitalist development is related to democracy because it shifts the balance of class power by weakening the power of the landlord class and strengthening subordinate classes. The working and the middle classes - unlike other subordinate classes in history -- gain an unprecedented capacity for self-organization due to such developments as urbanization, factory production, and new forms of communication and transportation. As to the role of the bourgeoisie, we dispute the claims of both liberal and Marxist political theory that democracy is the creation of the bourgeoisie. The bourgeoisie made important contributions to the move towards democracy by insisting on its share in political power in the form of parliamentary control of the state, but the bourgeoisie was also hostile to further democratization when its interests seemed threatened.

The structure of the state and state-society relations are clearly relevant for the chances of democracy. The state needs to be strong and autonomous enough to ensure the rule of law and avoid being the captive of the interests of dominant groups; the state's authority to make binding decisions in a territory and the state's monopoly of coercion must be settled. The vote does not rule where it competes with the gun. However, the power of the state needs to be counterbalanced by the organizational strength of civil society to make democracy possible; the state must not be so strong and autonomous from all social forces as to overpower civil society and rule without accountability. The third power cluster involves international power relations. Aside from the impact of war (typically creating a need for mass support and discrediting ruling groups in case of defeat), we focused on the role of economic and geopolitical dependence. The three power clusters -- relative class power, the role of the state, and the impact of transnational power structures -- are closely interrelated. For instance, economic dependency can have long term effects on the structures of class; war and geopolitical factors can strengthen the role of the security forces within the state; and the results of power relations in civil society are crucially affected by differential access to the state apparatus.

\footnotetext{
1 Our focus in this essay will be on the bourgeoisie in the context of the balance of class power, with only occasional references to the role of the state and the international system.
} 


\section{The European Experience}

The period 1870 to 1918 in Western Europe was a period of rapid industrialization and was also the critical transition period for the development of fully democratic political orders. In 1870, only one European country, Switzerland, was a democracy. Many countries frequently thought to be democratic at this time such as Britain, Netherlands, and Belgium, had parliamentary government and competitive party systems, but the electorate was limited by income or property qualifications. By contrast, by 1918 , almost all Western European countries were fully democratic. ${ }^{2}$

This period of transition to democracy in Europe was also marked by the arrival of the organized working class. Rapid industrialization greatly increased the size of the working class, but more impressive is the change in the level of working class organization. At the beginning of the period, both trade unions and social democratic parties were marginal phenomena in Western Europe; at the close of World War I, both were major forces in every Western European society. The organized working class was also the most consistently pro-democratic force in the period under consideration: at the onset of World War I, European labor movements had converged on an ideology which placed the achievement of universal suffrage and parliamentary government at the center of their program (Zolberg, 1986).

Though the working class was the main agent of democracy in Europe, it needed allies. It found them in the urban middle classes and the independent small farming population. Without these groups, the working class was too weak to press through full democracy. Indeed, in Switzerland and Norway, two countries which (like the north and west of the United States during the Jacksonian period) might be termed agrarian democracies, these groups were more important in the struggle for democracy than the working class. However, unlike the working class, both the urban middle classes and small farmers were not consistently pro-democratic: In some countries, they were ambivalent about the introduction of democracy and, in the interwar period, they provided mass support for fascism and other authoritarian movements which destroyed the new democratic regimes.

What was the role of the bourgeoisie, the class of the major owners of capital? In only three of the 13 European countries studied -- France, Switzerland, and Britain -- did any significant segment of the bourgeoisie play a leading role in promoting full democracy. Significantly, in all three of these cases, the bourgeoisie did not face a working class politically organized by socialist parties at the time of democratic transition; in ten of the other eleven countries, it did face such an opponent. Fear of challenges to property rights certainly played an important role in the reticence of propertied upper classes to support political inclusion of the working class.

As Barrington Moore argued, the existence of a powerful class of landlords dependent on a large supply of cheap labor was associated with significant problems for

\footnotetext{
2 In addition to the criteria of accountability, protection of civil and political rights, and regular free and fair elections, we chose the criterion of universal male suffrage for our classification of a system as a full democracy.
} 
democracy: In four of the five Western European countries in which large landholders played a significant political role towards the end of the nineteenth century -- Germany, Austria-Hungary, Spain and Italy -- democratic regimes collapsed in the interwar period. In each of these countries, the landed upper classes, in coalition with the state and the bourgeoisie, were crucially implicated in the weakness of the push toward democracy outside of the working class movement before World War I, and in the events that led to the demise of democracy in the interwar period. Again we highlight the anti-democratic role played by the bourgeoisie in these events.

In the post World War II period, with few exceptions, all major social groups and political parties in Western Europe came to embrace political democracy. In part, it was the thorough discrediting of the fascist alternative due to the fascist experience and, even more so, the devastation wrought by the war. But also a class compromise was struck. The working class movements abandoned their demands for socialism but received in return full employment, the welfare state, and industrial citizenship. While the terms of this compromise varied with the degree of working class political and organizational strength (Stephens 1979; Korpi 1983; Huber, Ragin and Stephens 1993), in every country, the material position of the working class relative to other classes was much better than in the early period. We want to underline this point as it has been contested by Marxist authors who claim that the reformist working class movements achieved nothing. Recent analyses of income distribution based on the Luxembourg Income Surveys conclusively demonstrate: (1) in every advanced industrial democracy, the welfare state effects some redistribution of income; (2) there is great variation in the redistributive impact of welfare states; and (3) the degree of redistribution effect by the welfare state is very strongly related to the strength of the working class movement in the country (Mitchell 1991; Atkinson, Rainwater, and Smeeding 1995; Huber, Ragin and Stephens 1993).

How did the Western bourgeoisies adapt to this compromise? They found that they could make money in ways which were compatible with working class interests. It is generally assumed that the essential element of this profit making strategy was Keynesian in that in entailed increasing working class consumption in order to provide a market for goods. While this is part of the story, it is not the most important part and moreover, if taken alone, leads to misleading conclusions about economic strategy (and democracy) in contemporary (post-Keynesian) Europe and Latin American as well as about the relevance of the European experience for the East Asian countries discussed elsewhere in this volume. The essential element of the economic strategy was investment in labor productivity enhancing technology which made it possible to increase private consumption, expand the welfare state and maintain profitability at the same time. In a word, these countries chose the "high road". The variant of this strategy followed by the small European countries in which social democracy was dominant, above all Scandinavia and Austria, serves to underline this point (Huber and Stephens 1997). These economies were by necessity dependent on foreign trade and thus were forced to fashion economic strategies in which their products were competitive on world markets. While most of these countries were Keynesian in the sense that their economic policies were counter cyclical, they were fiscally conservative across cycles running budget surpluses in the vast majority of years. These budget surpluses facilitated low interest rates and along with 
controlled financial markets and state subsidies stimulated high levels of investment which sustained the increases in labor productivity which were the center piece of the economic model. As Vartiainen (1996) points out, there are strong similarities between the economic strategies of these countries and the East Asian NICs.

Thus, even if it is admitted that the Keynesian era is over (and we are not sure we would go that far), a "high road" based on high productivity, high wage labor is still a viable economic strategy in the increasingly integrated world economy. And, indeed, despite the current difficulties of Western European economies in maintaining full employment and funding the welfare state, it is decidedly not the case that these countries, with the exception of the United Kingdom, have forsaken this strategy and are now attempting to compete on the basis of low wage costs. Thus, the class compromise on which the consolidation, stabilization, and routinization of Western European democracy was based is largely intact.

\section{Historic Developments in Latin America}

In analyzing the role of the bourgeoisie in the emergence of democracy in Latin America and the Caribbean one must begin with the caveat that it is problematic to see the bourgeoisie as a new, economically and sociologically distinct class from the landowning oligarchy. Of course, there is great variation; in some cases, immigrants became the early commercial and industrial entrepreneurs and thus did form a distinctive group; in others, large landowners invested in commercial and industrial ventures. Even where immigrants started out as a distinctive bourgeois segment, however, by the 1920s, when pressures for mass democracy intensified, they had by and large become a component of the dominant class, linked to landed interests through diversified holdings and family ties. ${ }^{3}$ Accordingly, one would not expect the bourgeoisie to have been a promoter of democracy. Where immigrants formed the core of the bourgeoisie, they typically were unable to rise to political prominence because they lacked citizenship and family connections. Where the bourgeoisie was an integral part of the dominant class, they did not differ much in their attitude towards democracy from the oligarchy.

Large landowners were rather universally opposed to full democratization. The intensity of their opposition depended on their need for large supplies of cheap labor, and their effectiveness in blocking democratization depended on their importance to the national economy and on the strength of the challenges. Breakthroughs to full democracy before the 1970s, even if temporary, were only possible where the large landowners were primarily engaged in ranching and thus had lower labor needs (Argentina and Uruguay), or where their economic power was undermined or counterbalanced by the presence of a strong mining export sector (Venezuela and Bolivia). Under some circumstances, sectors of the bourgeoisie along with sectors of the oligarchy promoted institutionalization of contestation, without full inclusion. This was true where crises of hegemony gave rise to

\footnotetext{
3 The best documented case of such an interconnected dominant class is Chile, thanks to the work of Zeitlin and Ratcliff (1988). We should reiterate here that we use the term bourgeoisie for large capitalists only; not for small entrepreneurs.
} 
political instability or even civil war (e.g. Uruguay 1903; Chile 1932; Ecuador 1948), or where military-backed dictators were excessively corrupt and inefficient (Venezuela and Colombia 1958).

The central actors pushing for initial democratization were the middle classes; urban professionals and employees in the public and private sectors, artisans and craftsmen, small entrepreneurs, and sometimes small and medium farmers. In comparison to Europe, the expansion of the export economies before the emergence of a significant degree of industrialization produced a working class that was smaller and orgnizationally weaker in relation to the middle classes and thus could not be the main carrier of the democratic impulse. However, the middle classes needed allies, and depending on these alliances, democracy took limited or inclusive forms. Where sectors of the oligarchy or the military allied with the middle classes, the middle classes were content with their own inclusion and supported literacy qualifications for the franchise (e.g. Brazil in the 1930s). In contrast, where the middle classes were dependent on working class support in their push for democracy and the working class had an organizational presence, these class coalitions were more likely to push for full democracy (e.g. Venezuela in the 1940s, Bolivia in the 1950s). However, where these subordinate class alliances were organized in radical mass parties that embraced programs threatening elite interests, they provoked counterreactions from the oligarchy and bourgeoise that led to breakdowns of democracy (e.g. Chile in the 1920s and 1970s; Peru in the 1930s and 1940s; Venezuela in the 1940s). What was needed was a delicate balance between pressures from below and threat perception at the top; pressures from below needed to be strong enough to induce elites to open up the system, but they could not be so strong - and in particular not accompanied by demands for redistributive socio-economic policies - as to threaten the perceived vital interests of the dominant classes.

Once democracy had been installed, the dominant class tolerated it as long as its interests were protected. Such protection could be afforded by state incorporation of lower classes as in Brazil under Vargas' estado novo (1937-45), by strong conservative political parties as in Chile after 1932, or by political pacts as in Colombia and Venezuela after 1958. Protection of elite interests was easier where organization in the rural sector was banned and the political articulation of the urban working and lower classes was mediated by clientelistic, non-ideological parties, rather than by ideological mass parties.

When the dominant class began to feel acutely threatened, it actively supported authoritarian alternatives to democracy and in most cases appealed to the military to bring about a change in government. In most cases, the breakdown of democracy occurred in the context of an economic crisis, and the perception of threat to dominant class interests was related to this crisis. Yet, by no means every economic crisis led to a breakdown. What was crucial was the fear that the established political mechanisms for the protection of elite interest were losing their effectiveness and state power might be used to deal with the economic crisis in a way that would affect elite interests negatively.

The type of authoritarian regime that followed the breakdown of a democratic one depended on the degree of industrialization reached. Where import 
substitution industrialization was in the early stages, traditional or populist authoritarian regimes were installed; where it had reached an advanced stage, bureaucratic-authoritarian regimes were imposed. Ironically, whereas the dominant class supported the installation of authoritarian regimes, they found themselves excluded from the policy-making circles in many of these regimes, particularly the populist authoritarian and the bureaucraticauthoritarian regimes, which gave them reason to begin to oppose these regimes, some sooner and some later. This opposition then became a contributing factor to the withdrawal of the military regimes and the democratization processes in the 1970s and 1980s.

\section{The Caribbean: Past and Present}

The case of the English-speaking Caribbean deserves some special discussion because we can draw on a particularly rich data base to sketch the process of the resistance of the bourgeoisie to the development of democracy and their eventual hedged accommodation to it. With the exception of Guyana, the bourgeoisie in these countries has not openly opposed democracy since the 1940s, when first elections with universal suffrage began to be held and the process of constitutional decolonization was set into motion. However, detailed historical monographs and interview data available for the Jamaican case allow us to examine the attitudes of the bourgeoisie towards democracy at four critical points in recent history, documenting their evolution from open hostility to thinly veiled distrust, then to self-confident if hedged accommodation. ${ }^{4}$

The origins of organized mass politics and the nationalist movement in Jamaica lie in the wave of labor unrest that swept the Caribbean between 1934 and 1938. Out of this unrest emerged first one and then two major unions and political parties, and one of these parties, the People's National Party (PNP) became the leading force in the push for democratization through universal suffrage, self-government and independence. The reaction of the dominant class, composed of planter and merchant interests, to the labor unrest was to deny the legitimacy of the grievances, blame outside agitators, and call for severe repression, including flogging, hanging, and shooting (Post 1978; Sherlock 1980). Since they did not control the state, and since the response of the British Colonial Office was much more measured, repression was mild and unions and political parties representing working and middle class interests were able to form and to grow.

\footnotetext{
4 See Stephens and Stephens (1990) for a more detailed analysis. Three interview studies using the same methodology were carried out by Moskos in 1962, immediately before Independence, (Moskos 1967), Bell and his associates in 1974, before the process of extreme political polarization under the later years of the Manley government (e.g. see Bell and Gibson 1978), and the present authors in 1982, after the defeat of Manley's government and his "democratic socialism" in the 1980 elections (Stephens and Stephens 1986). We also draw on interviews we conducted with businessmen in 1987 and a comprehensive survey of Jamaican businessmen carried out by Biddle in 1989 (1993). For the initial transition to competitive mass politics in 1938-1944, we draw on the detailed monographic work of Post (1978, 1981). Post's and Moskos' research covers the entire British West Indies while the Bell and Stephens and Stephens studies focus on Jamaica. Our analysis of Jamaica would hold for the rest of the West Indies until the radicalization of the Manley government in late 1974.
} 
In 1944, the first election based on universal suffrage was held, and subsequently constitutional reforms moved the colony slowly towards full self-government and independence in 1962. By that time, the two party-union blocs completely dominated Jamaican politics. The Jamaica Labour Party (JLP) bloc was strongly and consistently populist; the PNP bloc was originally Fabian socialist but in the 1950s pushed any such programmatic points onto the back burner. As it became clear that the parties did not intend on threatening capitalist interests, different segments of the bourgeoisie gained secure footholds in the two parties. Still, on the eve of independence the bourgeoisie was less than enthusiastic about the prospects of mass democracy. In the 1962 elite interviews, one-third of businessmen still expressed opposition to a "democratic form of government, such as the British system," and, more telling, two thirds were opposed to political independence. Of course, it was clear that mass public opinion was unanimously for independence, and therefore the bourgeoisie showed little opposition to it in public, but they clearly feared majority rule through universal suffrage.

The first ten years of independence, under a JLP government, did not present any particular challenges to bourgeois interests. This was to change under the PNP government led by Michael Manley, elected in 1972. In its first two and a half years in office, the government implemented a wide range of policies aimed at state sector expansion, redistribution, social inclusion, and political mobilization. The 1974 elite interviews were conducted before the PNP announced its renewed commitment to democratic socialism and thus show the impact of these policies but not of the ideological pronouncements. The bourgeoisie remained the least pro-democratic segment of the Jamaican elite, as one third of them opposed or at least expressed ambivalence towards democracy, and even those being favorable towards democracy saw its value primarily in the protection of civil liberties.

Between the radicalization of the PNP in late 1974 and the defeat of the Manley government in the 1980 elections, the vast majority of the members of the bourgeoisie perceived an acute threat to their interests from government policy and the deterioration of the economy, which they also blamed on the government. Not surprisingly, the PNP lost virtually all of its business support and a significant segment of the business class migrated to the United States. The reaction of those that remained was two-fold; on the one hand they began to prepare for the exit option by moving capital abroad, ${ }^{5}$ and on the other hand they resorted to voice, mainly through the reactionary but influential daily, The Gleaner, through increased support for the opposition JLP, and through the increased autonomous political mobilization of private sector interests. The combination of deteriorating living standards in the wake of IMF-imposed stabilization policies and the relentless opposition campaign resulted in a massive election defeat for Manley and the PNP in 1980. The new JLP government led by Edward Seaga fully embraced capitalism and the Reagan administration, and became a major beneficiary of U.S. assistance. Reagan hoped to make Jamaica the showcase for capitalism in the Caribbean.

5 The businessmen we interviewed in 1982 were very frank about this. 
By 1982, then, the bourgeoisie had moved back to center stage, at least in terms of the homage paid to its crucial role in promoting national development. In our interviews with businessmen that year, they expressed unqualified support for democratic government, though they strongly opposed any efforts to encourage popular participation which they associated with what they saw as the rhetorical excesses and irresponsible populist policies of the Manley government. The support for democracy was stimulated not only by Seaga's defeat of Manley in a democratic election but also by the strong support of the Reagan administration for the Seaga government and Reagan's anticommunist foreign policy which helped make the Caribbean safe for (capitalist) democracy, as the invasion of Grenada so clearly demonstrated. By the late eighties, Jamaican business expressed confidence that even a new PNP government would be supportive of business interests and, indeed, the PNP did move sharply in a neo-liberal direction after its election in 1989. Yet it is worth underlining that the bourgeois support for Jamaican democracy was qualified. Hedging their bets against a renewed radicalization of domestic politics by setting aside nest eggs in North America was still common behavior. ${ }^{6}$ In Jamaica, where the exit option is so easy and military takeover practically impossible, exit rather than class compromise is the probable bourgeois response to a surge in popular demands which finds expression in the policies of the sitting government, as in the case of the Manley government of the seventies.

\section{Transition, Consolidation, and Quality of Democracy in Contemporary Latin America}

The role of the bourgeoisie in the push for (re)democratization in Latin America has been ambiguous. In part, this is due to the heterogeneity of bourgeois interests and in part due to differences among the authoritarian regimes. Where the military had reformist designs and did not shy away from violating property rights, as in Peru, the bourgeoisie never really supported the regime. In contrast, as pointed out above, initially all sectors of the bourgeoise welcomed the military coups that set an end to popular mobilization and political confrontation in Argentina, Brazil, Chile, and Uruguay. Weaker and more nationalistic sectors of the bourgeoisie soon became disaffected (O'Donnell 1978), but even the stronger and more internationalized sectors eventually became disenchanted with the military governments' handling of the economic crisis of the 1980s. Their main concerns were the lack of stability and predictability of economic policy, and their own exclusion from economic policy-making (Payne and Bartell 1995: 266-70). Accordingly, they strongly supported liberalization, in particular the opening of policy-making to greater public scrutiny.

For the most part, though, the bourgeoisie remained concerned about mass democracy and what it might mean for property rights, taxes, and wages. The distrust of the opposition (and likely new government in case of a democratic transition) was probably deepest in Chile, where bourgeois interests had been challenged most dramatically by the Allende government. The Chilean military government was also the most economically successful regime in Latin America by the second half of the 1980s.

6 This assertion is based on interviews by Jesse Biddle (1993, personal conversation) conducted after the PNP's return to power. 
Thus, it is not surprising that the Chilean bourgeoisie continued to support Pinochet and candidates identified with his regime. In this context, statements by the center-left coalition and discussions prior to the 1990 elections between big business and the likely Christian Democratic Finance Minister under a government led by this coalition played a crucial role in reassuring the bourgeoisie that such a new government would remain committed to the neoliberal economic model - and all this meant for the guarantee of property rights and the privileged position of the bourgeoisie (Bartell 1995: 69-70).

Once the military regimes had initiated a process of liberalization, liberalization was pushed towards democratization by the resurgence of civil society - and by an increasingly favorable international environment. Organizations at all levels of society - from the bar and press associations at the upper end, middle-class professional and civic associations, cross-class human rights groups and women's groups, and unions and grass-roots neighborhood associations at the lower end of the social ladder - pushed for restoration of civil and political rights and for democratic elections. Given their alienation from the military regimes, members of the bourgeoisie were left with little choice other than accommodating to democracy and attempting to protect their interests through a variety of mechanisms. Business leaders formed new associations that developed partly intense activities, ranging from aggressive publicity campaigns against state-centered economic policies to business strikes in protest against government policies (Conaghan 1995: 117-9). Where political parties historically played an important role, business leaders attempted to work through such parties or to form new ones (Payne and Bartell 1995: 267). Control over media became a particularly important asset in bourgeois efforts to shape the political agenda.

The two questions for Latin America in the present juncture are whether democracy has been consolidated or is being consolidated, and what the quality of democracy is and likely will remain. If we take the widely accepted conceptualization of consolidation as the acceptance of the rules of the democratic game by all relevant actors and the abandonment of a search for any other routes to political power, and the resulting expectation among these actors and the public at large that democracy will persist for the foreseeable future (e.g. Schmitter 1992; Mainwaring et al. 1992), then we can state that democracy is being consolidated. However, if we inquire into the quality of the democratic system that is being consolidated, there is much more ambiguity. Most of the democracies in today's Latin America are deficient in one or more dimensions of formal democracy, not to speak of the reality of power sharing.

In general political practice, political systems are regarded as democratic if the legislature and executive come to power through regular free and apparently reasonably fair elections. Deficiencies in accountability of overpowering presidents confronting weak legislatures and judiciaries, in protection of civil and, to a lesser extent, political rights across classes, gender, and territorial units, and in the separation of public and private realms (O'Donnell 1996) are under less scrutiny and thus incur less international censure than violations of the norm of free and fair elections. O'Donnell (1994) has called systems with weak accountability and uneven protection of civil rights "delegative democracies," to emphasize the delegation of powers to a president who tends 
to see himself as the embodiment of the nation and thus the sole source of the definition of the national interest.

If we go beyond the definition of formal democracy and ask about the reality of power sharing, about popular participation in shaping political outcomes, and about the distributive impact of political decisions, the deficiencies become even more glaring. Popular organizations that could mobilize lower classes into participation, and political parties that represent lower class interests are weak. Income distributions in Latin America are among the most unequal in the world, and the wave of neoliberal reforms has tended to make them more rather than less unequal. So, how do we explain the survival of these deficient democracies, and what are the implications for the future?

To put the explanation in a somewhat provocative formulation, the democracies are surviving in part due to the international environment and in part precisely because they are deficient, particularly in the dimensions of equal protection of civil and political rights and in the capacity for participation of lower classes. ${ }^{7}$ The international environment is highly favorable for the survival of formal democracy. The end of the Cold War has removed the incentive for the United States to support authoritarian regimes because of their loyalty to the anti-communist cause. It has also deprived authoritarian regimes of an important legitimizing claim - that they are less vulnerable to communist subversion that democratic governments. Finally, solidaristic action among the democratically elected governments in Latin America against violators of the electoral principle has been a strong deterrent to the search for alternative routes to power.

Internally, challenges to democratic rule have come from the military (most visibly in Argentina and Paraguay) and from incumbents (Fujimori in Peru), but not really from the bourgeoisie. One reason why military challenges have not been more widespread is the ability of the military to preserve extensive prerogatives, prerogatives that constitute clear abridgments of accountability and thus formal democracy. The starkest examples here are Chile and Brazil (Stepan 1988). Another reason is the lack of support from the bourgeoisie for military challenges. In Argentina, where these challenges were particularly strong, the bourgeoisie feared the more radical currents behind these military uprisings and sided with democracy (Acuña 1995: 44).

In general, the bourgeoisie has had little reason to challenge democracy. After the first democratic elections, the upsurge of mobilization of old and new social movements that had made a crucial contribution to pushing liberalization towards democratization subsided for a variety of reasons. Moreover, in countries where neoliberal reforms intensified after the transition, labor unions were weakened further. Political parties that had historically promoted the interests of subordinate classes either failed miserably in their defiance of orthodox policies (Apra in Peru) or turned to

\footnotetext{
7 It is worth reminding the reader here briefly of our argument with regards to the balance of class power. We have argued that it takes a delicate balance between pressures from below and threat perception at the top to make the installation of democracy possible. For the transition, pressures from below were clearly necessary, but for consolidation a constellation of a low level of mobilization and even lower threat perception is favorable.
} 
neoliberal policies, under intense internal and external pressures (Peronists in Argentina; the PNP in Jamaica ${ }^{8}$ ). In Chile, where the historically strong link between left and center parties and popular forces had been drastically weakened by the dictatorship, the parties have been reluctant to reinvigorate these links. Thus, the capacity of subordinate classes to participate effectively in the political process and make demands for material benefits was weakened, which in turn has kept any potential threat to bourgeois interests extremely low. The position of the bourgeoisie has further been bolstered by external pressures for neoliberal adjustment. Guarantees of property rights and favorable investment climates are at the center of the "Washington consensus," backed by the formidable power of international financial institutions.

The Brazilian case offers a highly instructive example of successful bourgeois efforts to thwart reforms that could in any way affect their interests negatively. Businessmen and their political allies defeated a crucial job security measure in the Constituent Assembly, thus preserving their ability to fire union organizers and protest leaders. Large landowners, many of them linked to bourgeois interests, and their political allies blocked a land reform measure in the Constituent Assembly, and they used violence with impunity to intimidate or eliminate rural organizers and their supporters (Payne 1995: 226-45). Bourgeois interests were greatly aided in their efforts to block reform by the pervasiveness of clientelism and the organizational fragmentation of popular groups, of political parties, and of the state itself; factors which also obstructed redistributive reforms in other areas, such as social security (Weyland 1996).

An important deficiency in formal democracy in contemporary Latin America, the blurring of lines between the public and private realm through clientelistic relationships, further strengthens the privileged position that the bourgeoisie holds in all democracies (Lindblom 1977). Whereas subordinate classes have to rely on political institutions, in particular programmatic political parties but also judiciaries, to hold rulers accountable, and consequently are in a very weak position to do so where such institutions are feeble, the bourgeoisie can influence political leaders directly and is not hampered by institutional weakness. Fragmented and clientelistic parties may yield particularistic benefits for some among the subordinate classes, but they do not allow for control over leaders and enforcement of support for universalistic policies in favor of subordinate class interests. In contrast, the bourgeoisie has much more to contribute to clientelistic relations and much more direct means to retaliate for non-compliance with bargains on the part of political leaders.

In sum, great care was taken to protect property rights during the transition, in the context of a mobilized civil society; after the transition, mobilization subsided; the position of the bourgeoisie has been bolstered by external pressures for the implementation of neoliberal policies; these neoliberal policies have put the bourgeoisie at the center of the process of national development and let them experience the importance of their decisions; clientelistic relations and lack of democratic accountability have made access to political leaders much easier for the bourgeoisie than for representatives of

8 Of course, Jamaica does not belong to the new democracies, but otherwise the economic and political dynamics fit the pattern sketched here. 
subordinate classes; and international pressures have militated against the search for alternatives to formal democracy. Little wonder, then, that most members of the bourgeoisie have learned to live with democracy.

In contrast to Europe, however, bourgeois acceptance of democracy has not been accompanied by a class compromise giving subordinate classes a significant share of material benefits and a recognized role in a variety of decision-making bodies. On the contrary, the bourgeoisie insists on and the orthodox neoliberal model presupposes absolute protection of property rights, low wages, and consequently a weak labor movement. The triumphs of the Brazilian bourgeoisie in defeating all significant reform proposals in these areas starkly illustrate this reality. Where private investment, domestic and foreign, is the sole engine of growth, investor confidence is indispensable, which in turn obstructs attempts to modify property rights for purposes of redistribution or employment preservation. Competition in the world economy on the basis of low skill products requires that wages and other labor costs be kept low enough to compete with ever new entrants. Though there is a growing recognition among some governments and international institutions that states have an important role to play in pushing economies up the product cycle through investments in labor quality, labor productivity enhancing technology and infrastructure, the bourgeoisie doesn't really see it this way and uses its power to oppose such measures, particularly their financing.

The Chilean case is instructive here. The inter-party agreement on tax increases to finance social spending concluded under the new democratic government in 1990 is generally considered a model for fiscally responsible redistributive reform. Indeed, the poverty rate was reduced from roughly 40 to 30 percent of the population. However, the measures for increased taxation were limited to four years (Boylan 1996:21), and their effect did not change the distribution of income at the top, where the top 10 percent continued to receive around 40 percent of total income (Martínez and Díaz 1996: 125). Moreover, the share of national income attributable to wages declined between 1990 and 1992 (ibid.). Permanent progress in reduction of poverty and inequality would require a change in the economic model. This model continues to rely on extremely low wages and precarious employment, protected by labor legislation aimed at flexibility of labor markets. A change would require more access to education and training, more investment in labor productivity enhancing technology, and a more equitable distribution of the revenue from increases in productivity (Martínez and Díaz 1996: 129). Such changes in turn would be dependent upon and compatible with a strengthening of labor organization, which in the longer run could become a strong basis for a reformist political coalition. So far, the bourgeoisie has strenuously opposed labor law reform that would facilitate such a strengthening of labor organization.

Since most governments in the region have subscribed to the neoliberal model and labor unions have been too weak to challenge it, those sectors of the bourgeoisie who have weathered the transition from the closed to the open economic model have little to fear from democracy. And in most countries, these are the only bourgeois sectors that really matter. The process of rapid liberalization of trade and finance and of privatization of public sector enterprises has led to a concentration of assets in the hands of large conglomerates. This concentration of economic power has also 
produced a shift in political power within the private sector from medium enterprises and domestically oriented entrepreneurs towards large and internationally oriented conglomerates. In Brazil and to some extent Mexico, with their large internal markets, there are significant splits in the bourgeoisie between the smaller, domestically oriented and the larger, internationally oriented entrepreneurs, but even there liberalization and privatization have greatly strengthened the latter and weakened the former.

It is no surprise, then, that those members of the business community who are successful in competing in open markets express self-confidence with regard to their economic and political roles and a general acceptance of democracy (e.g. Bartell 1995). However, this self-confidence does not induce them to become complacent vis-a-vis potential challenges. On the contrary, business groups mobilize against efforts to change labor legislation in ways that would strengthen unions and against efforts of popular groups to bring about redistribution through increased taxes and social expenditures. So far, they have been highly successful in limiting the political agenda and keeping demands from labor and the left off of it. Should their political strength relative to that of unions and popular sectors change, though, their acceptance of democracy might well be endangered (Payne and Bartell 1995: 270-80).

\section{Conclusion}

Our historical overview of the role of the bourgeoisie in the development of democracy in Western Europe, Latin America, and the Caribbean has shown that the bourgeoisie was not a promoter of full formal democracy as it is conventionally defined. When its interests have been strongly challenged by demands from working class and other popular movements, it has opted for authoritarian solutions if allies for such a move, large landholders in Europe and large landholders and/or the military in Latin America, were available. The stabilization of democracy and the conversion of the bourgeoisie to a strong supporter of democracy in post World War II Europe was predicated not only on elimination of potential authoritarian allies but also on a class compromise in which the material and political interests of the working class could be accommodated. This in turn was predicated on the adoption of an economic growth model in which the essential element of the economic strategy was investment in labor productivity enhancing technology which resulted in competitive high wage export sectors. This in turn made it possible to increase private consumption, expand the welfare state and maintain profitability at the same time.

Because neither landlords nor the bourgeoisie controlled the state in the British Caribbean at critical junctures of the initiation of democratic transition, unions and parties were allowed to flourish and a militarization of the state was prevented. This forced the bourgeoisie into reluctant and conditional compromise with new democracies at the same time as a shift to the right on the part of the democratic independence movement encouraged such a move. While a sort of class compromise with urban labor was worked out, it was one which was based on uncompetitive manufacturing and was supported by primary product exports. Given the absence of the military option and the deep social interconnection to North America and Britain, it is not surprising that the response of the 
bourgeoisie to strong challenges from the left, as in the case of the Manley government in Jamaica, was exit and voice rather than moves in an authoritarian direction.

With the neo-liberal turn, Caribbean tariffs came down and the rudimentary class compromise with urban labor was largely undone. While the highly competitive and successful tourism sector with its unionized labor force has produced economic advance for all involved in the sector, it has had relatively little spill over into other sectors of the economy. Indeed, the other successful non primary product export sector, the export platforms, are predicated on low wage, nonunionized labor. The political results of the neo-liberal turn are the weakening of unions and other popular organizations and falling political participation rates. While party government remains vibrant, the corrosion of the judicial system and abuse of police power due to the high levels of violence bred by economic exclusion and political clientelism continue to be a blight on even formal democracy in the Caribbean.

In Latin America in the 1970s and 1980s the bourgeoisie began to oppose the military regimes it had initially welcomed. The major concerns were the unpredictability of economic policy and the bourgeoisie's own exclusion from policymaking. What the bourgeoisie pressed for most was liberalization, in particular greater respect for civil rights and an opening of the policy-making process. What the bourgeoisie got was democratization. A resurging civil society pressed for a widening of the political space opened up by liberalization until the military's cost/benefit calculation on repression versus withdrawal induced them to hand power back to civilians (O'Donnell and Schmitter 1986). However, the democracies that emerged have been deficient even in formal criteria, and even more so in the reality of power sharing. The bourgeoisie adapted very quickly to working in the new political environment, successfully limiting the political agenda and blocking any major redistributive initiatives.

The dominant economic model in Latin America tends to reinforce the strength of those sectors of the bourgeoisie that have survived the opening of the economy. Assets have become concentrated in their hands. Their investment decisions are absolutely crucial for the economic welfare of their countries, and they have international financial institutions on their side when they demand a favorable investment climate. Only few of them are engaged in comparatively high skill/ high productivity/ high wage production for export. Most of them are competing in world markets on the basis of low wages, and all of them believe that the ability to depress wages and keep labor weak is important for their success. Even in Brazil, where there is a significant sector of high skill/ high productivity export production, the bourgeoisie successfully mobilized against changes that had the potential of allowing for stronger labor organization. Labor is being kept weak not only by high unemployment and the shrinking of the traditionally well organized public sector, but also by labor legislation in the name of flexibility of labor markets. The political consequences are only feeble challenges to the status quo and only weak organized social bases for programmatic mass parties. By default, clientelism and lack of accountability are the principles by which governing elites operate.

On the basis of this assessment, one can sketch a pessimistic and an optimistic scenario for the coming decade in Latin America. The pessimistic scenario 
begins with the assumption of continuing adherence to the neo-liberal, low wage, weak labor model and continuing cycles of economic growth and crises. Such crises are likely to spark protests and social conflict, which in turn would be met by bourgeois and political elite support for curtailments of civil and political rights. In the name of law and order, further curtailments of accountability of the security forces and the executive would ensue, as happened in Peru under Fujimori. In short, this scenario ends in serious erosion of formal democracy.

The optimistic scenario begins with the assumption of sustained - if moderate- economic growth and a gradual recuperation of the state's capacity for economic intervention, particularly in providing adequate education and skill training and incentives for upgrading of productivity. Higher levels of employment and higher skill levels, particularly if accompanied by some enabling labor law reforms, would strengthen labor organization. Tighter labor markets and a labor movement growing slowly in strength could bring about gradual expansion of collective negotiation and thus induce the bourgeoisie to make further efforts at industrial upgrading. A stronger organized social base for programmatic parties and a stronger economic base, resulting from these efforts at industrial upgrading, could result not only in the improvement of formal democracy through a strengthening of accountability but also in a slow expansion of social programs. ${ }^{9}$ Stronger democratic institutions and redistributive social programs, grounded in an economic model aimed at continuous upgrading, in turn could lay the basis for the construction of a class compromise compatible with an internationally competitive, open economy.

\footnotetext{
9 A likely objection to this scenario is that it overemphasizes the role of labor, given that in many Latin American countries formal wage labor constitutes a minority of the total labor force. Two counterarguments can be made. First, in order for an economic model to be successful in the new international environment, it has to produce for export, and export production by and large depends on wage labor. For instance, in Chile the proportion of wage and salary earners among the economically active population reached 63 percent by 1992 (Martínez and Díaz 1996: 103). Many of them do work without contracts, that is, informally, for firms supplying exporters, but this is precisely our point; changes in labor legislation could extend the benefits of formal employment to them. Second, political activation has to come from those sectors of the underprivileged who have some access to resouces, such as a stable income and skills. It is no accident that the most successful new programmatic mass party in Latin America has been the PT in Brazil.
} 


\section{References}

Acuña, Carlos. 1995. "Business Interests, Dictatorship, and Democracy in Argentina." In Ernest Bartell and Leigh A. Payne (eds.), Business and Democracy in Latin America. Pittsburgh: University of Pittsburgh Press.

Atkinson, Anthony B., Lee Rainwater, and Timothy Smeeding. 1995. Income Distribution in OECD Countries: Evidence from the Luxembourg Income Study. Paris: OECD.

Bartell, Ernest. 1995. "Perceptions by Business Leaders and the Transition to Democracy in Chile." In Ernest Bartell and Leigh A. Payne (eds.), Business and Democracy in Latin America. Pittsburgh: University of Pittsburgh Press.

Bell, Wendell and J. William Gibson. 1978. "Independent Jamaica Faces the Outside World." International Studies Quarterly 22(1):5-47.

Biddle, W. Jesse. 1993. "Business Elites, the State, and Development: Jamaica in Comparative Perspective." Ph.D. dissertation, Brown University.

Boylan, Delia. 1996. "Taxation and Transition: The Politics of the 1990 Chilean Tax Reform." Latin American Research Review 31 (1) 7-32.

Conahan, Catherine. 1995. "The Private Sector and the Public Transcript." In Ernest Bartell and Leigh A. Payne (eds.), Business and Democracy in Latin America. Pittsburgh: University of Pittsburgh Press.

Huber, Evelyne, Charles Ragin, and John D. Stephens. 1993. "Social Democracy, Christian Democracy, Constitutional Structure and the Welfare State." American Journal of Sociology 99 (3): 711-49.

Huber, Evelyne, and John D. Stephens. 1997. "Internationalization and the Social Democratic Model: Crisis and Future Prospects." Comparative Political Studies.

Korpi, Walter. 1983. The Democratic Class Struggle. London: Routledge and Kegan Paul.

Lindblom, Charles, 1977. Politics and Markets. New York: Basic Books.

Mainwaring, Scott, Guillermo O'Donnell and J. Samuel Valenzuela (eds.), Issues in Democratic Consolidation: The New South American Democracies in Comparative Perspective. Notre Dame, IN: University of Notre Dame Press.

Martínez, Javier, and Alvaro Díaz. 1996. Chile: The Great Transformation. Washington: Brookings.

Mitchell, Deborah. 1991. Income Transfers in Ten Welfare States. Brookfield: Avebury. 
Moskos, Charles, The Sociology of Political Independence. Cambridge: Schenkman, 1967.

O'Donnell, Guillermo. 1996. "Illusions About Consolidation," Journal of Democracy 7 (2).

1994. "Delegative Democracy", Journal of Democracy, 5 (1).

1978. "Reflections on the Bureaucratic Authoritarian State." Latin American Research Review 13 (1).

1973. Modernization and Bureaucratic Authoritarianism. Berkeley: University of California at Berkeley, Institute of International Studies.

O'Donnell, Guillermo, and Phillippe Schmitter. 1986. Transitions from Authoritarian Rule: Tentative Conclusions about Uncertain Democracies. Baltimore: Johns Hopkins University Press.

Payne, Leigh, and Ernest Bartell. 1995. "Bringing Business Back In: Business-State Relations and Democratic Stability in Latin America." In Ernest Bartell and Leigh A. Payne (eds.), Business and Democracy in Latin America. Pittsburgh: University of Pittsburgh Press.

Post, Ken. 1978. Arise Ye Starvlings. The Hague: Martinus Nijhoff.

1981. Strike the Iron. The Hague: Martinus Nijhoff.

Rueschemeyer, Dietrich, Evelyne Huber Stephens, and John D. Stephens, Capitalist Development and Democracy. Chicago: Chicago University Press, 1992.

Schmitter, Phillippe. 1992. "Consolidation and Interest Systems." In Larry Diamond and Gary Marks (eds.), Comparative Perspectives on Democracy: Essays in Honor of Seymour Martin Lipset; American Behavioral Scientist 35, 4 and 5.

Sherlock, Philip. 1980. Norman Manley: A Biography. London: Macmillan.

Stepan, Alfred C. 1988. Rethinking Military Politics: Brazil and the Southern Cone. Princeton: Princeton University Press.

Stephens, John D. 1979. The Transition from Capitalism to Socialism. Urbana: University of Illinois Press.

Stephens, Evelyne Huber and John D. Stephens. 1986. Democratic Socialism in Jamaica: The Political Movement and Social Transformation in Dependent Capitalism. Princeton: Princeton University Press.

Stephens, Evelyne Huber, and John D. Stephens. 1990. "Capitalists, Socialism, and Democracy: An Analysis of Business Attitudes Towards Political Democracy in Jamaica" Comparative Social Research 12: 341-79. 
Therborn, Göran. 1977. "The Rule of Capital and the Rise of Democracy" New Left Review 103.

Vartiainen, Juhana. 1996. "The State and Late Industrialization." In Douglas Hibbs (ed.), Politics, Growth, and Distribution. Oxford: Oxford University Press.

Weyland, Kurt. 1996. "Obstacles to Social Reform in Brazil's New Democracy." Compartive Politics 29 (1): 1-22.

Zeitlin, Maurice, and Richard Ratcliff. 1988. Landlords and Capitalists: The Dominant Class of Chile. Princeton: Princeton University Press.

Zolberg, Aristide R., " How Many Exceptionalisms?" In: Ira Katznelson and Aristide Zolberg, eds., Working Class Formation: Nineteenth Century Patterns in Western Europe and the United States. Princeton: Princeton University Press, 1986. 